\title{
Clinical use of alprostadil topical cream in patients with erectile dysfunction: a review
}

\author{
This article was published in the following Dove Press journal: \\ Research and Reports in Urology \\ 3 August 2016 \\ Number of times this article has been viewed
}

\section{James Anaissie Wayne JG Hellstrom}

Department of Urology, Tulane University School of Medicine, New Orleans, LA, USA
Correspondence: Wayne J G Hellstrom Department of Urology, Tulane University Health Sciences Center, 1430 Tulane Ave, New Orleans, LA 70II2, USA

Tel + I 504988336 I

Fax + I 5049885059

Email whellst@tulane.edu
Abstract: Erectile dysfunction (ED) is a common and debilitating disorder seen in over $50 \%$ of men older than 70 years. Oral phosphodiesterase type 5 (PDE5) inhibitors are the mainstay of treatment for ED, but cannot be used by a significant subset of patients due to systemic side effects and drug-drug interactions. Second-line therapy may include intracavernosal therapies, but are associated with poor compliance due to their invasive nature. Alprostadil has a mechanism of action different from that of PDE5 inhibitors. Clinical trials have shown topical alprostadil cream to be effective, increasing the erectile function (EF) score of the International Index of EF by up to 13 points from baseline. It has also proven to be safe and well tolerated, with mildto-moderate and transient treatment-related adverse events that are generally localized to the application site. Topical alprostadil cream is a safe and effective second-line therapy for ED, indicated for those who cannot tolerate, or are not satisfied with, oral PDE5 inhibitor therapy.

Keywords: erectile dysfunction, topical cream, second-line treatment, alprostadil

\section{Introduction}

Erectile dysfunction (ED), defined as the consistent inability to achieve or maintain an erection satisfactory for sexual intercourse, is a common and debilitating disorder. ${ }^{1}$ Although observed in $2 \%-10 \%$ of men less than 50 years old, the prevalence increases dramatically with age, climbing to $30 \%-40 \%$ in men between 60 and 70 years old, and reaching over $50 \%$ in men older than 70 years. $^{2-4}$

An increase in the aging population has brought ED to the forefront of sexual medicine. This condition is strongly associated with the comorbidities observed in this aged population, such as cardiovascular disease and depression, and also with common medications such as antihypertensive agents and alpha-blockers. It has been shown that the presence of comorbid conditions, particularly cardiovascular and metabolic, increases the absolute risk of ED by $\sim 10 \%{ }^{5,6}$ ED can also be of psychogenic origin, as given in Table 1, but is usually a combination of both organic and psychogenic causes. ${ }^{1}$

The treatment of ED has been shown to improve the quality of life and overall satisfaction for both patients and their partners. ${ }^{7}$ According to the American Urological Association guidelines for the management of ED, oral phosphodiesterase type 5 (PDE5) inhibitors constitute the first line of therapy. ${ }^{8}$ Although oral PDE5 inhibitors are generally effective, they are associated with treatment failure in up to half of patients, resulting in discontinuation due to either noneffectiveness or psychosocial reasons. ${ }^{9}$ Additionally, oral PDE5 inhibitors are associated with systemic side effects and are 
Table I Organic and psychogenic origins of erectile dysfunction

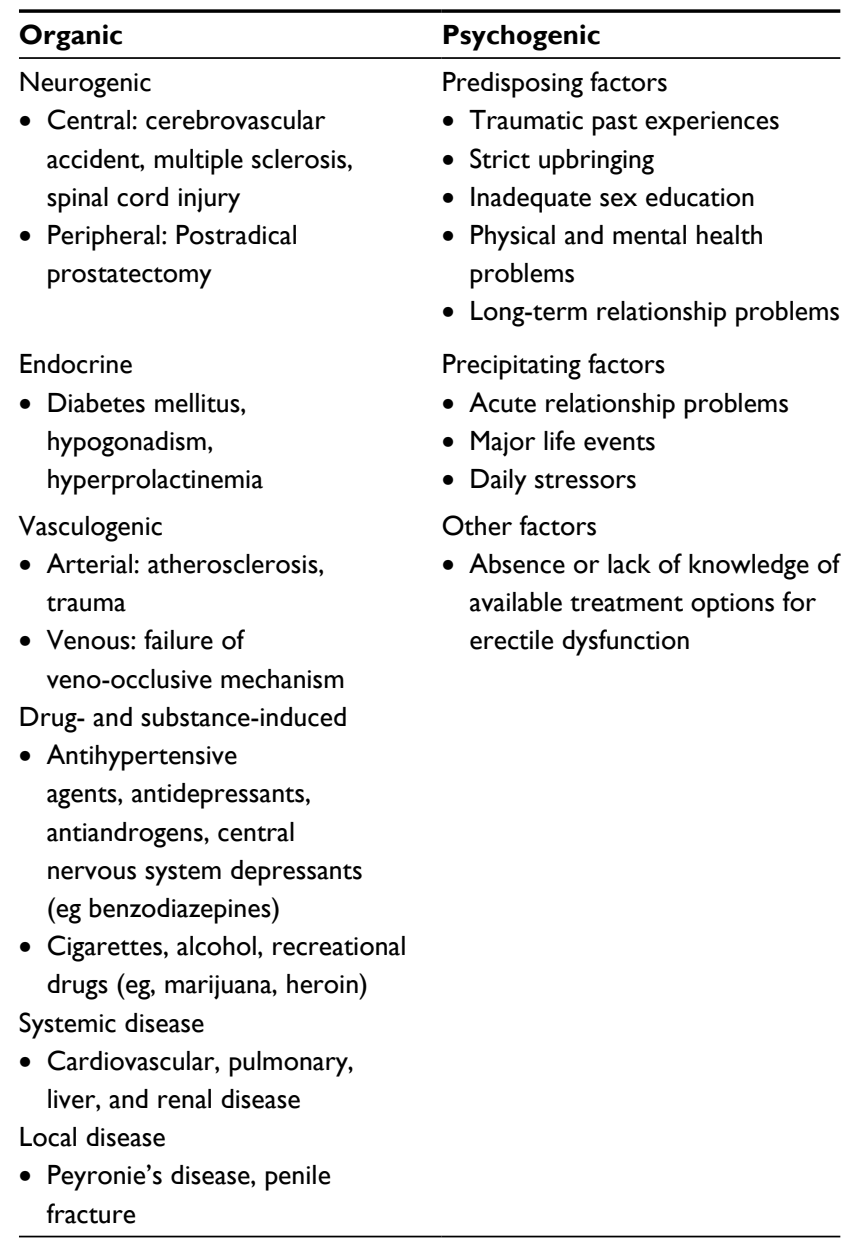

contraindicated with the use of nitrates, a cardiovascular agent commonly used in this older population. ${ }^{10}$ Limitations of treatment with oral PDE5 inhibitors obviate the need for second-line treatment options, which include intracavernosal injection therapy, vacuum erection devices, intraurethral alprostadil, and topical alprostadil cream.

The clinical applications of topical alprostadil cream are discussed in this article, including its efficacy and safety.

\section{Pathophysiology of ED}

The primary neurotransmitter involved in achieving and maintaining a penile erection is nitric oxide (NO), which is released from the penile endothelium and parasympathetic nerve terminals following sexual stimulation. ${ }^{11} \mathrm{NO}$ relaxes the cavernosal smooth muscle, compressing the veins in the penis and occluding local venous return, resulting in an erection. NO utilizes the guanosine triphosphate and cyclic guanosine monophosphate (cGMP) pathway by stimulating cGMP to decrease intracellular calcium, which leads to the cavernosal smooth muscle relaxation that is needed for erection. PDE5 is an enzyme that counteracts this relaxation by facilitating the degradation of cGMP, and PDE5 inhibitors are effective in promoting erection longevity (Figure 1). ${ }^{12}$

Normal sexual function involves the coordination of psychological, endocrine, vascular, and neurological systems, and disruption in any of these pathways can lead to ED. ${ }^{1}$ Most commonly observed, however, is the vasculogenic form of

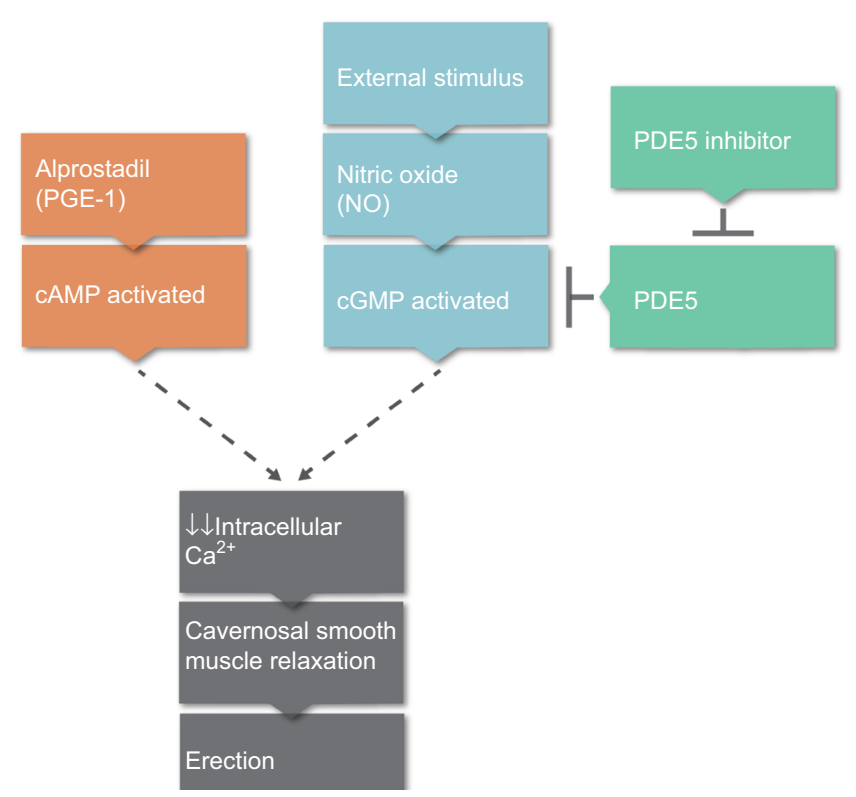

Figure I Physiological pathway to erectile response.

Notes: Normally (in blue), erection begins with an external stimulus, leading to an accumulation of nitric oxide (NO). NO then activates cGMP, leading to a decrease in the amount of intracellular calcium $\left(\mathrm{Ca}^{2+}\right)$, which relaxes cavernosal smooth muscle and leads to erection. Alprostadil (in orange), a prostaglandin EI (PGEI) analog, utilizes the cAMP pathway to decrease intracellular calcium, leading to erection. PDE5 inhibitors (in green) block PDE5, an enzyme which degrades the cGMP needed for erection, thus prolonging the duration of externally stimulated erection.

Abbreviations: PGEI, prostaglandin EI; cAMP, cyclic adenosine monophosphate; cGMP, cyclic guanosine monophosphate; PDE5, phosphodiesterase type 5. 
ED as suggested by studies in which $49 \%$ of patients with angiographically documented coronary artery disease also have ED. ${ }^{11,13}$ Additional conditions that may lead to penile arterial insufficiency and subsequent ED include atherosclerosis, hypertension, and diabetes mellitus. The relationship between these conditions and ED is so strong that studies have shown ED to be a strong predictor of cardiovascular disease. ${ }^{14}$ Indeed, men less than 60 years old with ED have a marked increase in the risk of future cardiac events compared to those without ED. ${ }^{15}$

A better understanding of the pathophysiology and causes of ED has led to the development of multiple medical treatment options. Treatment can alleviate the psychological burden associated with ED and the associated lower quality of life.

\section{Overview of treatment of ED}

Choosing the appropriate treatment for ED is important, given the multiple etiologies and the negative impact that the disease can have on a patient's life. An exhaustive review of the available treatments for ED is beyond the scope of this manuscript, but relevant descriptions of the first- and second-line treatments for ED are provided in the following section.

\section{First-line treatment}

The organic and psychosocial conditions that contribute to the development of ED (Table 1) should be identified and appropriately treated before beginning medical treatment for ED. If the cause is determined to be psychogenic, psychosexual counseling (sometimes in combination with a PDE5 inhibitor) is recommended. ${ }^{8}$ Patients with cardiovascular comorbidities should be counseled on lifestyle modifications and treated for diseases that contribute to ED. These most commonly include cardiovascular processes, but early identification of an underlying hormonal or endocrine cause may lead to a more targeted therapy and the subsequent resolution of ED. Although counseling and management of comorbidities are important first steps, medical treatment is often needed to effectively treat ED.

Oral PDE5 inhibitors, unless contraindicated, should be utilized as the first-line medical therapy for ED. ${ }^{8}$ As shown in Figure 1, PDE5 inhibitors function by blocking the enzyme responsible for degradation of cGMP, a molecule needed for smooth muscle relaxation, leading to increased cGMP concentrations and maintenance of erection. Four PDE5 inhibitors are currently approved by the US Food and Drug Administration (FDA) for the treatment of ED: sildenafil,
Table 2 Limitations and adverse events of erectile dysfunction (ED) treatment with phosphodiesterase type 5 (PDE5) inhibitors

\begin{tabular}{ll}
\hline Limitation & Adverse event \\
\hline Systemic side effects & - Headache \\
& - Visual disturbance \\
- Priapism & - Flushing \\
& - Muscular pain \\
& - Dyspepsia \\
& - Sinus congestion \\
& - Variable efficacy as a result \\
- Inhibitors/inducers of P-450* & of increased/decreased PDE5 \\
- Antihypertensive agents & inhibitor plasma concentration \\
- Alpha-blockers** & - Enhanced variable efficacy \\
- Nitrates & - Severe hypotension \\
Decreased absorption with fatty & - Decreased efficacy \\
meals & - Loss of spontaneity \\
\hline
\end{tabular}

Notes: *Cytochrome P-450 inhibitors; **alpha-blockers are used for the treatment of hypertension and benign prostatic hyperplasia.

tadalafil, avanafil, and vardenafil, each with a variable time to and duration of efficacy. Overall, a response rate of $\sim 70 \%$ is achieved within 12-24 weeks of treatment.

Several factors may, however, limit the use of oral PDE5 inhibitors, as shown in Table 2. ${ }^{10,16}$ In surveys of sildenafiltreated patients, $46 \%$ had reported discontinued treatment, and $76 \%$ of those patients were not satisfied with the results. ${ }^{17}$ This may be due the aforementioned limitations or to the difficulty in planning sexual activity around the use of the medication (onset of action $\geq 1$ hour), with subsequent loss of sexual spontaneity. Further, ED following a radical pelvic surgery such as radical prostatectomy is often refractory to treatment with PDE5 inhibitors. Although oral PDE5 inhibitors have set the standard for treating ED, limitations to their use including these contraindications, adverse events (AEs), and high discontinuation rates often necessitate an alternative treatment. ${ }^{18}$

\section{Second-line treatment}

Intracavernous injections with phentolamine, papaverine, and alprostadil are considered the second-line treatment for ED, although alprostadil is most commonly used. This approach is at least as effective as treatment with oral PDE5 inhibitors and has the advantage of a more rapid onset of action. ${ }^{19-22}$ Intracavernosal therapy is also often effective in ED refractory to treatment with oral PDE5 inhibitors, especially in post-radical prostatectomy patients. ${ }^{23-26}$ Despite these benefits, intracavernosal therapy is an invasive procedure that is associated with dropout rates as high as $40 \%-50 \%$ due to pain, priapism, penile fibrosis, hematoma, ecchymosis, or fear of the needle. ${ }^{21,27,28}$ 
Alprostadil can also be administered intraurethrally, by inserting a pellet into the urethral meatus and allowing the absorption of the drug into the corpora cavernosa. Although less invasive, this method results in less of an erectile response than intracavernosal injections, and is also associated with high rates of discontinuation due to urethral pain and bleeding. ${ }^{29-32}$

Given the limitations of both oral PDE5 inhibitors and intracavernosal injection, a new medical approach is needed to improve the therapeutic index when managing ED. Alprostadil topical cream may serve as an important second-line treatment for ED.

\section{Alprostadil topical cream Mechanism of action}

Alprostadil is a synthetic analog of prostaglandin E1 (PGE1). Its mechanism of action involves binding to $G$ proteins coupled to PGE1 receptors on the surface of smooth muscle cells, activating cyclic adenosine monophosphate (cAMP) pathway and thus inducing vascular smooth muscle relaxation and erection. Unlike PDE5 inhibitors, which utilize the NO pathway, alprostadil's action as a direct agonist means that it can produce erection independent of a stimulus. ${ }^{33}$

Novel fatty acid and fatty alcohol esters are employed in alprostadil topical cream. These molecules are chemically and structurally similar to two of the primary skin building blocks: proteins and lipids. These structural similarities temporarily loosen the tight junctions present in skin epithelial cells, allowing for enhanced skin permeation at the site of application, usually the glans penis. . $3,34^{2}$

\section{Pharmacodynamics}

Topical alprostadil has a favorable pharmacodynamic profile. Using a laser Doppler flow meter, one study showed that the microcirculation of the glans improved rapidly after administration of topical alprostadil, reaching values expected in a physiologically normal erection. Full rigidity was observed within 10-12 minutes of application and lasted for longer than 1 hour. ${ }^{33}$ In another study, gamma-scintigraphy performed in patients receiving topical alprostadil showed that $99 \%$ of the cream was retained in the fossa navicularis of the penis, minimizing systemic migration of the drug. ${ }^{33,35}$ When compared with intracavernosal injection of alprostadil, the topical formulation showed a similar penile hemodynamic profile. ${ }^{33}$

\section{Pharmacokinetics}

The pharmacokinetic profile of topical alprostadil cream has been analyzed in a double-blind, placebo-controlled trial. In this trial, the plasma concentrations of PGE1 and its metabolites were measured at multiple time points after topical application. ${ }^{29,33}$ At the majority of these time points, the plasma levels of PGE1 and its metabolites were undetectable, implying either a very low level of systemic absorption or a rapid metabolism.

On the other hand, the time to maximum concentration of PGE1 metabolites at the site of topical alprostadil was achieved within 1 hour after its application.

\section{Efficacy}

Clinical trials have demonstrated that topical alprostadil cream is an effective alternative to the conventional treatment of ED. The first such trial was conducted in 1999, where erectile response, skin discomfort, and erythema were measured in 48 men with ED after the application of topical PGE1 soft enhancer of percutaneous absorption gel in a single-blind, placebo controlled trial. ${ }^{36}$ Use of the gel led to an erectile response in $67 \%-75 \%$ of patients at varying doses, compared to $17 \%$ of controls $(P<0.001)$, with no serious AEs. More recent trials are summarized in Table 3.

A double-blind, placebo-controlled, efficacy study of $1 \%$ alprostadil topical gel for the treatment of ED further confirmed the drug's efficacy. ${ }^{37}$ Sixty subjects received placebo gel at the first office visit; 2 weeks later, 29 received placebo and 31 were given alprostadil gel. After inducing erection, both the physician and the patient assessed the patient's erection at 15-minute intervals during the first hour and 90 minutes after the initial application. A significant difference in erectile response was first apparent at 45 minutes, with the mean angle of erection for the alprostadil group reaching $42.9^{\circ}$ vs $32.4^{\circ}$ among the placebo group. The alprostadil group also had a higher mean change from baseline in angle of erection vs placebo $\left(24.2^{\circ}\right.$ vs $\left.13.5^{\circ}, P=0.039\right)$ and a greater maximum rigidity $(P=0.033)$. The erection was sufficient for vaginal penetration in $12(38.7 \%)$ of the alprostadil-treated patients compared to only two (6.9\%) in the placebo group $(P=0.005)$.

In two multicenter, double-blind, placebo-controlled Phase II studies, patients with mild-to-moderate (study 1) or severe (study 2) ED were randomized to receive placebo, 50,100 , or $200 \mu \mathrm{g}$ topical alprostadil in study 1 , or placebo, 100,200 , or $300 \mu \mathrm{g}$ topical alprostadil in study $2 .{ }^{38}$ Mild-tomoderate ED was defined as patients with an International Index of Erectile Function (IIEF) score between 14 and 21. The topical cream was dispensed to the tip of the penis and was held upright to maximize absorption. The primary efficacy end point was change in the erectile function (EF) domain score of the IIEF from baseline. Secondary end points 
Table 3 Efficacy and safety of topical alprostadil cream for the treatment of erectile dysfunction: summary of key clinical trials

\begin{tabular}{|c|c|c|c|c|c|c|}
\hline Study & Design & Patient population & $\begin{array}{l}\text { Topical alprostadil } \\
\text { dosage }\end{array}$ & Efficacy & \multicolumn{2}{|c|}{$\begin{array}{l}\text { Treatment-related adverse } \\
\text { events }^{\mathrm{a}}\end{array}$} \\
\hline $\begin{array}{l}\text { Goldstein } \\
\text { et } \mathrm{al}^{37}\end{array}$ & $\begin{array}{l}\text { Phase I: RCT } \\
{[I: I]}\end{array}$ & $\begin{array}{l}n=60 \\
31 \text {, alprostadil 29, placebo }\end{array}$ & $1 \%$ alprostadil $+5 \%$ SEPA & $\begin{array}{l}\text { Improvement in vaginal } \\
\text { penetration: } \\
|2 / 3|(39 \%) \text { in } \\
\text { alprostadil vs } 2 / 29(7 \%) \\
\text { in placebo, } P<0.005\end{array}$ & $\begin{array}{l}30 \% \text { - placebo } \\
50 \% \text { - alprostadil }\end{array}$ & \\
\hline $\begin{array}{l}\text { Padma- } \\
\text { Nathan } \\
\text { et } \text { a }^{38}\end{array}$ & $\begin{array}{l}\text { Phase II: } \\
\text { multicenter, } \\
\text { double-blind, } \\
\text { placebo- } \\
\text { controlled } \\
\text { RCT [3:I] }\end{array}$ & $\begin{array}{l}\mathrm{n}=303 \\
\text { I6I (study I) - mild-to- } \\
\text { moderate ED } \\
\text { I2I, alprostadil } \\
40 \text {, placebo } \\
\text { 142 (study 2) - severe ED } \\
107 \text {, alprostadil } \\
35 \text {, placebo }\end{array}$ & $\begin{array}{l}\text { Study I - 50, } 100 \text {, or } 200 \mu \mathrm{g} \\
\text { Study } 2-100,200 \text {, or } 300 \mu \mathrm{g}\end{array}$ & $\begin{array}{l}\text { Change in EF domain } \\
\text { of IIEF from baseline: } \\
\text { Study I: } 3.7 \pm 1.2 \text { in } \\
\text { alprostadil vs. }-0.8 \pm \mathrm{I} \text {.I } \\
\text { in placebo, } P<0.0 \mathrm{I} \\
\text { Study } 2: 9.4 \pm \mathrm{I} .5 \text { in } \\
\text { alprostadil vs. } 2.7 \pm \mathrm{I} .3 \\
\text { in placebo, } P<0.0 \mathrm{I}\end{array}$ & $\begin{array}{l}\text { Study I: } \\
53 \% \text { - placebo } \\
67 \% \text { - } 50 \mu \mathrm{g} \\
67 \% \text { - } 100 \mu \mathrm{g} \\
78 \% \text { - } 200 \mu \mathrm{g} \\
\text { Discontinuation } \\
\text { due to AE: I4\% }\end{array}$ & $\begin{array}{l}\text { Study 2: } \\
\text { II\% - placebo } \\
30 \%-100 \mu \mathrm{g} \\
60 \%-200 \mu \mathrm{g} \\
51 \%-300 \mu \mathrm{g} \\
\text { Discontinuation } \\
\text { due to AE: II\% }\end{array}$ \\
\hline $\begin{array}{l}\text { Padma- } \\
\text { Nathan } \\
\text { et a }\left.\right|^{40}\end{array}$ & $\begin{array}{l}\text { Phase III: } \\
\text { multicenter, } \\
\text { double-blind, } \\
\text { placebo- } \\
\text { controlled, } \\
\text { long-term } \\
\text { RCT [3:I] }\end{array}$ & $\begin{array}{l}\mathrm{n}=1,732 \\
\mathrm{I}, 298, \text { alprostadil } \\
\text { 434, placebo }\end{array}$ & 100,200 , or $300 \mu g$ & $\begin{array}{l}\text { Change in EF domain } \\
\text { of IIEF from baseline } \\
(P<0.00 \mathrm{I}) \text { : } \\
\text { I.6 for } 100 \mu \mathrm{g} \\
2.5 \text { for } 200 \mu \mathrm{g} \\
2.4 \text { for } 300 \mu \mathrm{g} \\
-0.7 \text { for placebo }\end{array}$ & $\begin{array}{l}12 \% \text { - placebo } \\
46 \% \text { - } 100 \mu \mathrm{g} 62 \\
67 \% \text { - } 300 \mu \mathrm{g} \\
\text { Discontinuation }\end{array}$ & $\begin{array}{l}\% \text { - } 200 \mu g \\
\text { Jue to } A E: 2.7 \%\end{array}$ \\
\hline $\begin{array}{l}\text { Rooney } \\
\text { et al }{ }^{44}\end{array}$ & $\begin{array}{l}\text { Open label: } \\
\text { multicenter, } \\
\text { long-term }{ }^{\text {e }} \text { study }\end{array}$ & $n=1,10 \mid$ & $\begin{array}{l}\text { Before titration: } \\
\text { I, I0I, } 200 \mu \mathrm{g} \\
\text { After titration: } \\
\text { 25, } 100 \mu \mathrm{g} \\
\text { I24, } 200 \mu \mathrm{g} \\
846,300 \mu \mathrm{g}\end{array}$ & $\begin{array}{l}\text { Change in } E F \text { domain } \\
\text { of IIEF from baseline } \\
\begin{array}{l}(P<0.00 \mathrm{I}) \text { : } \\
\text { I3.0 for } 100 \mu \mathrm{g} \\
13.2 \text { for } 200 \mu \mathrm{g} \\
10.1 \text { for } 300 \mu \mathrm{g}\end{array}\end{array}$ & $\begin{array}{l}\text { Before titration: } \\
23 \%-200 \mu g \\
\text { After titration: } 3 \\
42 \%-200 \mu g 34 \\
\text { Discontinuation }\end{array}$ & $\begin{array}{l}\text { \% - } 100 \mu g \\
\%-300 \mu g \\
\text { tue to AE: } 4.3 \%\end{array}$ \\
\hline
\end{tabular}

Notes: ${ }^{\mathrm{T}}$ Treatment-related adverse events (AEs) usually included penile burning, genital pain, and erythema, which resolved within 2 hours; ${ }^{\mathrm{b}} \mathrm{mild}$-to-moderate ED defined as IIEF I4-2I; csevere EF defined as IIEF <I4; dong term defined as 3 months in this study; elong term defined as 9 months in this study.

Abbreviations: RCT, randomized control trial; SEPA, soft enhancer of percutaneous absorption; ED, erectile dysfunction; EF, erectile function; IIEF, International Index of Erectile Function.

included overall IIEF score, questions three and four of the IIEF, successful vaginal penetration, and global assessment questionnaire (GAQ). Study 2 was identical to study 1 with the exception of the severity of ED (defined as IIEF <14) and the doses of alprostadil used. In total, 303 patients were enrolled (161 in study 1 and 142 in study 2). In both studies, the primary efficacy end point was significantly increased at the maximum dose in a dose-dependent manner. In study 1 , the EF domain score change from baseline was $-0.8 \pm 1.1$ in the placebo group vs $3.7 \pm 1.2$ in the $200 \mu \mathrm{g}$ treatment group $(P<0.01)$. In study 2 , the change in EF domain score relative to baseline was $2.7 \pm 1.3$ for the placebo group vs $9.4 \pm 1.5$ for the treatment group (mean \pm standard deviation; $P<0.01)$. In both studies, the change in total IIEF score was also significant for the maximum dosage group: $1.7 \pm 2.2$ in the placebo group vs $7.3 \pm 2.5$ in the $200 \mu$ group ( $P=0.05$, study 1$)$, and $6.24 \pm 2.67$ in the placebo group vs $17.65 \pm 2.92$ in the $300 \mu$ g group $(P<0.05$, study 2$)$. The vaginal penetration rate was significantly greater for the $200 \mu \mathrm{g}$ group than placebo in study 1 but did not achieve statistical significance in study 2. At least some improvement in erection was noted in the GAQ for the maximum doses in both studies $(P<0.001)$. These investigations demonstrated that topical alprostadil is effective in a population with a broad range of ED intensity.

These positive findings were confirmed in a metaanalysis of the aforementioned Phase II studies ${ }^{38,39}$ in which all 303 patients were assigned to one of five groups: placebo, 50,100, 200, or $300 \mu \mathrm{g}$ of alprostadil topical cream combined with a skin-permeation-enhancing agent. The same primary and secondary efficacy end points were used. The change in EF score was significantly increased, in a dose-dependent fashion, in the $100 \mu \mathrm{g}(P=0.049), 200$ $\mu \mathrm{g}(P<0.001)$, and $300 \mu \mathrm{g}(P<0.001)$ treatment groups relative to placebo $(\mathrm{EF}$ domain $=3.40,5.34$, and 9.44, respectively, vs 0.98 for the placebo group). IIEF questions three and four and the rates of successful vaginal penetration were also significantly increased at almost all dosage levels. Similarly, the percentage of patients showing at least some improvement in erection on the GAQ significantly improved, relative to placebo, in all treatment groups. The results from this meta-analysis demonstrated that most efficacy end points increased significantly with 
topical alprostadil administration, and usually in a dosedependent fashion.

An integrated analysis of two multicenter, randomized, double-blind, Phase III trials studied the effects of topical alprostadil cream in 1,732 patients with ED. ${ }^{40}$ Patients with a baseline IIEF $<25$ were randomized into either placebo group or topical alprostadil cream dose groups of 100, 200, or 300 $\mu \mathrm{g}$ for 12 weeks. Primary end points included change in the EF domain of the IIEF, rate of vaginal penetration, ability to maintain erections until ejaculation, and GAQ scores. A significant improvement in the mean change in IIEF domain scores from baseline was observed among the alprostadiltreated patients and those given placebo $(P<0.001)$. The vaginal penetration rate and maintenance of erection until ejaculation changed only slightly in all treatment groups but were significantly different when compared to placebo $(P<0.001)$. Lastly, patient satisfaction on the GAQ showed a significant $(P<0.001)$ dose-dependent improvement vs placebo subjects. However, although the primary end points in the topical alprostadil group were significantly improved vs placebo, the authors felt that the magnitude of the changes was relatively low when compared to the scores seen in clinical trials of the FDA-approved PDE5 inhibitors. ${ }^{41-43}$ The improvements observed were also more modest than those shown in previously described alprostadil trials, which could be attributed to the inclusion of patients with a large variety of comorbidities and the higher age of trial subjects (mean age of 60 years), with $37 \%$ of patients older than 65 years. The authors concluded that topical alprostadil cream provides a modest improvement in EF.

A multicenter, open-label, long-term study of the efficacy of topical alprostadil was conducted in 2009 among 1,101 subjects with ED. ${ }^{44}$ Over $85 \%$ of the patients had participated in either of the two previously described Phase III clinical trials. ${ }^{38}$ For the first 4 weeks of the study, patients were administered, twice weekly, up to eight doses of $200 \mu \mathrm{g}$ alprostadil before intercourse. Patients were then allowed to move the dose up to $300 \mu \mathrm{g}$ if their response was suboptimal, down to $100 \mu \mathrm{g}$ in the event of an excellent response, or to maintain the $200 \mu \mathrm{g}$ dose, for up to 9 months. The primary efficacy end point was the change from baseline in the EF domain score of the IIEF. Secondary efficacy end points included vaginal penetration, maintenance of erection until ejaculation, and GAQ score. After the 4-week period, 25 patients $(2.2 \%)$ titrated the dose down to $100 \mu \mathrm{g}, 846$ patients $(72.8 \%)$ increased it to $300 \mu \mathrm{g}$, and 124 patients $(10.7 \%)$ continued the $200 \mu \mathrm{g}$ dose. After 9 months, all groups showed $\sim 100 \%$ improvement in the IIEF domain score from baseline (7.5,
13.2, and 10.6 for the 100,200 , and $300 \mu \mathrm{g}$ alprostadil doses, respectively) to the last visit $(20.5,26.4$, and 20.7 for the 100 , 200 , and $300 \mu \mathrm{g}$ alprostadil doses, respectively). Significant increases were also observed in all secondary outcome variables. Notably, dose-adjustment after 4 weeks led to improvement in most outcome variables when compared to maintaining the initial dose.

These trials have shown topical alprostadil cream to be an effective therapy for ED, providing an alternative treatment for patients with contraindications to, or intolerance of, oral PDE5 inhibitor therapy. However, many of the alprostadil studies included patients exclusively with vascular ED, limiting our understanding of its effects among patients with ED of neurogenic or endocrine etiologies. Similarly, differences in efficacy in circumcised patients when compared to those who are uncircumcised have not yet been evaluated for this drug. More long-term trials are needed to further elucidate the efficacy of and adherence to this novel treatment.

\section{Safety}

Several trials (Table 3) have shown alprostadil cream to be a safe treatment for ED, including the previously described double-blind, placebo-controlled study of $1 \%$ alprostadil topical gel, which also examined safety. ${ }^{37}$ Fifteen minutes after gel application, significantly greater erythema was reported in the alprostadil group than in the placebo group $(P<0.001)$. This was maintained throughout the 90 -minute observation period, but reached a peak 45 minutes after application. Overall, a higher frequency of minimal erythema or a pink, uniform discoloration at the application site was observed in the alprostadil vs placebo group.

In a combined analysis of the Phase II programs, ${ }^{37}$ the safety and tolerability of topical alprostadil cream was monitored using an unbiased query survey obtained during all clinic visits. Most AEs were localized to the site of application and included genital pain, tenderness, and erythema. Over $97 \%$ of patients described the AE as mild in intensity and short in duration ( $\leq 60$ minutes). One 10-minute nearsyncopal episode was reported after a treatment dose of 200 $\mu \mathrm{g}$. Approximately $2 \%$ of the AEs were partner reported, including vaginal burning ( $\leq 60$ minutes).

Overall, there was an association between topical alprostadil cream and AEs, although a dose-dependent relationship was difficult to identify. However, the rates of discontinuation due to AEs suggested a dose-dependent relationship in both studies. ${ }^{37}$

In the integrated analysis of two multicenter, randomized, double-blind, Phase III trials, ${ }^{38}$ the safety of topical 
alprostadil cream in the 1,732 patients with ED was also examined. ${ }^{40}$ Most AEs were mild to moderate, and no serious treatment-related AEs (TRAEs) were reported. Although the most frequently reported TRAE was at the application site, including penile burning, genital pain, and erythema, and resolved within 2 hours, 46 patients $(2.7 \%)$ withdrew from the study due to AEs. Approximately 5.6\% of all AEs were partner related, mainly mild vaginal burning, and all of them resolved in less than 2 hours. Only five partners $(0.4 \%)$ withdrew from the study due to AEs.

The safety of topical alprostadil cream was also examined in the open-label, long-term study of 1,101 patients with ED. ${ }^{44}$ Overall, topical alprostadil cream was well tolerated. Only 50 patients $(4.3 \%)$ discontinued treatment because of a TRAE, and only four $(0.3 \%)$ discontinuations were due to the partner. In addition, over $85 \%$ of participants had previously undergone 12 weeks of topical alprostadil treatment in an earlier study, indicating that previous and continued application of topical alprostadil cream was acceptable by this patient population. The most frequently reported AEs considered possibly, probably, or definitely related to treatment were application site burning or erythema and pain, which were observed in $1 \%$ of patients and were generally mild and transient. The most common complaint of partners was vaginal burning or itching. Twenty-four $(2.1 \%)$ patients and one $(0.1 \%)$ partner reported a serious AE after the initial dose, but only three AEs $(0.3 \%)$ were considered possibly or probably treatment related. These events included moderate sinus bradycardia, moderately abnormal electrocardiogram, and moderate dizziness and hypotension. Overall, a similar frequency of the most common AEs was observed in the 100,200 , and $300 \mu \mathrm{g}$ groups, suggesting that AEs may not be dose dependent.

Several other medications were used simultaneously with topical alprostadil cream in the aforementioned studies, including antihypertensive drugs, diuretics, nonsteroidal antiinflammatory drugs, antihyperglycemic agents, antilipidemic drugs, and thyroid replacement, without any evidence of interactions between alprostadil and these agents, unlike what is usually observed with oral PDE5 inhibitors.

Again, it is important to note that topical alprostadil cream also demonstrates safety with sexual partners, as only $2 \%-6 \%$ of female partners experienced AEs, namely vaginal burning. ${ }^{40,44}$ If used with pregnant sexual partners, it may be advisable to utilize a male condom, and similarly a condom can be used to prevent vaginal burning or itching.

The available literature suggests that topical alprostadil cream is a safe and well-tolerated treatment and has significant potential as a second-line treatment for ED.

\section{Indications}

Alprostadil topical cream can serve as second-line therapy for patients who fail to respond to, or are intolerant of, oral PDE5 inhibitors, and for those in whom these agents are contraindicated or may cause drug-drug interactions. ${ }^{38-40}$ The lack of interference with food and alcohol is another advantage, as it allows for a higher degree of sexual spontaneity. ${ }^{16}$ Alprostadil topical cream obviates the need for the invasive nature and side effects of the intracavernous/ transurethral administration of alprostadil. It is believed that circumnavigating these issues can address many of the problems encountered with currently available ED therapy and may decrease the relatively high discontinuation rate observed with the current standard of care.

\section{Conclusion}

Topical alprostadil cream has proven to be an effective and well-tolerated treatment for ED and can be safely used in men undergoing therapy with alpha-blockers, antihypertensive agents, and/or nitrates. The demonstrated efficacy and safety make topical alprostadil cream a safe alternative to those with contraindications to oral PDE5 inhibitors or those who cannot tolerate their systemic side effects. Clinical trials involving the medical management of patients with nonvascular etiologies of ED, and patients with multiple comorbidities, are needed to fully characterize the efficacy and safety profile of topical alprostadil cream.

\section{Disclosure}

The authors report no conflicts of interest in this work.

\section{References}

1. Shamloul R, Ghanem H. Erectile dysfunction. Lancet. 2013; 381(9861):153-165.

2. Braun M, Wassmer G, Klotz T, Reifenrath B, Mathers M, Engelmann $\mathrm{U}$. Epidemiology of erectile dysfunction: results of the 'Cologne Male Survey'. Int J Impot Res. 2000;12(6):305-311.

3. Lewis RW, Fugl-Meyer KS, Corona G, et al. Definitions/epidemiology/ risk factors for sexual dysfunction. JSex Med.2010;7(4 Pt 2):1598-1607.

4. Araujo AB, Travison TG, Ganz P, et al. Erectile dysfunction and mortality. J Sex Med. 2009;6(9):2445-2454.

5. Feldman HA, Goldstein I, Hatzichristou DG, Krane RJ, McKinlay JB. Impotence and its medical and psychosocial correlates: results of the Massachusetts male aging study. J Urol. 1994;151(1):54-61.

6. Bacon CG, Mittleman MA, Kawachi I, Giovannucci E, Glasser DB, Rimm EB. Sexual function in men older than 50 years of age: results from the health professionals follow-up study. Ann Intern Med. 2003;139(3):161-168.

7. Latini DM, Penson DF, Lubeck DP, Wallace KL, Henning JM, Lue TF. Longitudinal differences in disease specific quality of life in men with erectile dysfunction: results from the exploratory comprehensive evaluation of erectile dysfunction study. JUrol. 2003;169(4):1437-1442.

8. Montague DK, Jarow JP, Broderick GA, et al. The management of erectile dysfunction: an AUA update. J Urol. 2005;174(1):230-239. 
9. Carvalheira AA, Pereira NM, Maroco J, Forjaz V. Dropout in the treatment of erectile dysfunction with PDE5: a study on predictors and a qualitative analysis of reasons for discontinuation. $J$ Sex Med. 2012;9(9):2361-2369.

10. Schwartz BG, Kloner RA. Drug interactions with phosphodiesterase-5 inhibitors used for the treatment of erectile dysfunction or pulmonary hypertension. Circulation. 2010;122(1):88-95.

11. Lue TF. Erectile dysfunction. N Engl J Med. 2000;342(24):1802-1813.

12. Saenz de Tejada I. Molecular mechanisms for the regulation of penile smooth muscle contractility. Int J Impot Res. 2002;14(Suppl 1): S6-S10.

13. Montorsi F, Briganti A, Salonia A, et al. Erectile dysfunction prevalence, time of onset and association with risk factors in 300 consecutive patients with acute chest pain and angiographically documented coronary artery disease. Eur Urol. 2003;44(3):360-364.

14. Nehra A, Jackson G, Miner M, et al. The Princeton III consensus recommendations for the management of erectile dysfunction and cardiovascular disease. Mayo Clin Proc. 2012;87(8): 766-778.

15. Inman BA, Sauver JL, Jacobson DJ, et al. A population-based, longitudinal study of erectile dysfunction and future coronary artery disease. Mayo Clin Proc. 2009;84(2):108-113.

16. Mehrotra N, Gupta M, Kovar A, Meibohm B. The role of pharmacokinetics and pharmacodynamics in phosphodiesterase- 5 inhibitor therapy. Int J Impot Res. 2007;19(3):253-264.

17. Pryor JL, Redmon B. New therapies and delivery mechanisms for treatment of erectile dysfunction. Int J Impot Res. 2000;12(Suppl 4):S158-S162.

18. Giuliano F, Amar E, Chevallier D, Montaigne O, Joubert JM, ChartierKastler E. How urologists manage erectile dysfunction after radical prostatectomy: a national survey (REPAIR) by the French urological association. J Sex Med. 2008;5(2):448-457.

19. Lea AP, Bryson HM, Balfour JA. Intracavernous alprostadil. A review of its pharmacodynamic and pharmacokinetic properties and therapeutic potential in erectile dysfunction. Drugs Aging. 1996;8(1):56-74.

20. Heaton JP, Lording D, Liu SN, et al. Intracavernosal alprostadil is effective for the treatment of erectile dysfunction in diabetic men. Int J Impot Res. 2001;13(6):317-321.

21. Linet OI, Ogrinc FG. Efficacy and safety of intracavernosal alprostadil in men with erectile dysfunction. The Alprostadil Study Group. NEngl J Med. 1996;334(14):873-877.

22. Mancini M, Raina R, Agarwal A, Nerva F, Colpi GM. Sildenafil citrate vs intracavernous alprostadil for patients with arteriogenic erectile dysfunction: a randomised placebo controlled study. Int J Impot Res. 2004;16(1):8-12.

23. Shabsigh R, Padma-Nathan H, Gittleman M, McMurray J, Kaufman $\mathrm{J}$, Goldstein I. Intracavernous alprostadil alfadex (EDEX/VIRIDAL) is effective and safe in patients with erectile dysfunction after failing sildenafil (Viagra). Urology. 2000;55(4):477-480.

24. Garrido Abad P, Sinues Ojas B, Martinez Blazquez L, Conde Caturla P, Fernandez Arjona M. Safety and efficacy of intraurethral alprostadil in patients with erectile dysfunction refractory to treatment using phosphodiesterase-5 inhibitors. Actas Urol Esp. 2015;39(10): 635-640.

25. Yiou R, Cunin P, de la Taille A, et al. Sexual rehabilitation and penile pain associated with intracavernous alprostadil after radical prostatectomy. J Sex Med. 2011;8(2):575-582.
26. Yiou R, Ebrahiminia V, Mouracade P, Lingombet O, Abbou C. Sexual quality of life in women partnered with men using intracavernous alprostadil injections after radical prostatectomy. J Sex Med. 2013;10(5):1355-1362.

27. Porst $H$. The rationale for prostaglandin $E 1$ in erectile failure: a survey of worldwide experience. J Urol. 1996;155(3):802-815.

28. Lakin MM, Montague DK, VanderBrug Medendorp S, Tesar L, Schover LR. Intracavernous injection therapy: analysis of results and complications. J Urol. 1990;143(6):1138-1141.

29. Hanchanale V, Eardley I. Alprostadil for the treatment of impotence. Expert Opin Pharmacother. 2014;15(3):421-428.

30. Padma-Nathan H, Hellstrom WJ, Kaiser FE, et al. Treatment of men with erectile dysfunction with transurethral alprostadil. Medicated Urethral System for Erection (MUSE) Study Group. NEngl J Med. 1997;336(1):1-7.

31. Porst $H$. Transurethral alprostadil with MUSE (medicated urethral system for erection) vs intracavernous alprostadil - a comparative study in 103 patients with erectile dysfunction. Int J Impot Res. 1997;9(4):187-192.

32. Kim SC, Ahn TY, Choi HK, et al. Multicenter study of the treatment of erectile dysfunction with transurethral alprostadil (MUSE) in Korea. Int J Impot Res. 2000;12(2):97-101.

33. Becher E. Topical alprostadil cream for the treatment of erectile dysfunction. Expert Opin Pharmacother. 2004;5(3):623-632.

34. Wolka AM, Rytting JH, Reed BL, Finnin BC. The interaction of the penetration enhancer DDAIP with a phospholipid model membrane. Int J Pharm. 2004;271(1-2):5-10.

35. Yeager J, Beihn RM. Retention and migration of alprostadil cream applied topically to the glans meatus for erectile dysfunction. Int $J$ Impot Res. 2005;17(1):91-95.

36. McVary KT, Polepalle S, Riggi S, Pelham RW. Topical prostaglandin E1 SEPA gel for the treatment of erectile dysfunction. J Urol. 1999;162(3 Pt 1):726-730.

37. Goldstein I, Payton TR, Schechter PJ. A double-blind, placebocontrolled, efficacy and safety study of topical gel formulation of $1 \%$ alprostadil (Topiglan) for the in-office treatment of erectile dysfunction. Urology. 2001;57(2):301-305.

38. Padma-Nathan H, Steidle C, Salem S, Tayse N, Yeager J, Harning R. The efficacy and safety of a topical alprostadil cream, Alprox-TD, for the treatment of erectile dysfunction: two phase 2 studies in mild-tomoderate and severe ED. Int J Impot Res. 2003;15(1):10-17.

39. Steidle C, Padma-Nathan H, Salem S, et al. Topical alprostadil cream for the treatment of erectile dysfunction: a combined analysis of the phase II program. Urology. 2002;60(6):1077-1082.

40. Padma-Nathan H, Yeager JL. An integrated analysis of alprostadil topical cream for the treatment of erectile dysfunction in 1732 patients. Urology. 2006;68(2):386-391.

41. Padma-Nathan H, McMurray JG, Pullman WE, et al. On-demand IC351 (Cialis) enhances erectile function in patients with erectile dysfunction. Int J Impot Res. 2001;13(1):2-9.

42. Anderson PC, Gommersall L, Hayne D, Arya M, Patel HR. New phosphodiesterase inhibitors in the treatment of erectile dysfunction. Expert Opin Pharmacother. 2004;5(11):2241-2249.

43. Young JM. Vardenafil. Expert Opin Investig Drugs. 2002;11(10): 1487-1496.

44. Rooney M, Pfister W, Mahoney M, Nelson M, Yeager J, Steidle C. Long-term, multicenter study of the safety and efficacy of topical alprostadil cream in male patients with erectile dysfunction. $J$ Sex Med. 2009;6(2):520-534. 
Research and Reports in Urology is an international, peer-reviewed, open access journal publishing original research, reports, editorials, reviews and commentaries on all aspects of adult and pediatric urology in the clinic and laboratory including the following topics: Pathology, pathophysiology of urological disease; Investigation and treatment of urological disease; Pharmacology of drugs used for the treatment of urological disease. The manuscript management system is completely online and includes a very quick and fair peer-review system, which is all easy to use. Visit http://www.dovepress.com/testimonials.php to read real quotes from published authors.

Submit your manuscript here: https://www.dovepress.com/research-and-reports-in-urology-journal 